\title{
MULTIFUNGSI LAHAN PARKIR JALUR BARU WISATA OLAHRAGA BANDARA SYAMSUDINNOR BANJARBARU
}

\author{
Erico Krisna Bayu \\ Fakultas Keguruan dan Ilmu Pendidikan Universitas Lambung Mangkurat \\ ericokrisna07@gmail.com
}

\begin{abstract}
Abstrak
Demam gowes atau bersepeda merupakan olahraga yang kini tengah naik daun akibat dari pandemi covid-19. Demam olahraga sepeda dan juga jogging kini terjadi hampir diseluruh daerah di Indonesia tidak terkecuali di Banjarbaru. Pihak dari bandara Syamsudinnor sendiri juga menyediakan berbagai fasilitas untuk para pesepeda, orang-orang jogging dan juga senam pagi khusus untuk hari minggu. Fasilitas yang disediakan seperti jalur khusus untuk para sepeda, tempat parkir khusus sepeda yang terletak di sebelah masjid di bandara syamsudinnor, dan juga ruang parkir terbuka di depan gedung administrasi untuk keperluan senam minggu pagi. Artikel ini tentu didukung dengan sumber yang relevan dari tulisan dosen Pendidikan IPS Universitas Lambung Mangkurat (ULM).
\end{abstract}

\section{KATA KUNCI : Pembelajaran, Wisata, Covid-19. PENDAHULUAN}

Pada masa pandemi Covid-19 ini, tentu memunculkan hobi-hobi baru yang sebelumnya kurang digemari namun sekarang menjadi marak bermunculan khususnya di daerah Kalimantan Selatan terutama di Banjarbaru. Hobi yang dimaksud disini yaitu hobi olahraga yang tentu sangat ber impact baik bagi masyarakat di masa pandemi seperti ini. Berbagai macam hobi yang beraroma olahraga seperti Jogging, senam, dan yang paling banyak dijumpai sekarang yaitu bersepeda. Beraneka ragam olahraga tersebut sangat sering kita jumpai di kota-kota besar pada masa pandemi Covid-19 saat ini. Pandemi Covid-19 ini beresiko menyebabkan pola sedentary lifestyle dalam kehidupan manusia (Kunjung Ashadi, Laily Mita Andriana, dan Bayu Agung Pramono, 2020). Yang berarti bahwa pada pandemi Covid-19 ini, diwajibkan untuk tetap berada di rumah selama kurun waktu yang tidak ditentukan dan pada akhirnya seharusnya menyebabkan masyarakat mengalami kemalasan dalam berolahraga dikarenakan dominan berada di dalam rumah. Akan tetapi, jika masyarakat tidak melakukan olahraga atau kemalasan dalam hal bergerak, maka penyebaran Covid-19 ataupun penyakit lainnya seiring waktu akan menghampiri juga. Kesadaran akan hal itulah yang membuat antusias masyarakat terhadap olahraga untuk menjaga kesehatan 
dan kebugaran tubuh dengan tetap memprioritaskan protokol kesehatan menjadi semakin meningkat. Oleh karena itu, untuk memfasilitasi antusias masyarakat terhadap olahraga outdoor tersebut pihak dari Bandara Syamsudinnor Banjarbaru membuat area khusus untuk masyarakat berolahraga khususnya Jogging, senam, dan bersepeda, dengan memodifikasi area pintu masuk yang baru di daerah belakang Bandara Syamsudinnor menjadi kawasan yang mendukung untuk aktifitas olahraga masyarakat.

\section{PEMBAHASAN}

Demam gowes atau bersepeda merupakan olahraga yang kini tengah naik daun akibat dari pandemi covid-19. Demam olahraga sepeda dan juga jogging kini terjadi hampir diseluruh daerah di Indonesia tidak terkecuali di Banjarbaru. Pihak dari bandara Syamsudinnor sendiri juga menyediakan berbagai fasilitas untuk para pesepeda, orang-orang jogging dan juga senam pagi khusus untuk hari minggu. Fasilitas yang disediakan seperti jalur khusus untuk para sepeda, tempat parkir khusus sepeda yang terletak di sebelah masjid di bandara syamsudinnor, dan juga ruang parkir terbuka di depan gedung administrasi untuk keperluan senam minggu pagi.

Banyak sekali orang yang datang untuk berolahraga setiap harinya dari berbagai kalangan. Dari orang tua, remaja, anak-anak hingga para komunitas sepeda yang ada di Banjarbaru. Dari berbagai komunitas sepeda yang telah saya temui menyebutkan bahwa jalur yang ada di Bandara Syamsudinnor ini sangat bersahabat bagi para pesepeda maupun bagi

yang berolahraga jogging, dikarenakan jalur yang sangat luas dan udara yang menyelimuti kawasan bandara sangatlah sejuk sehingga membuat kondisi tubuh sangat segar.

Pada awalnya jalur dibelakang bandara ini dibuat untuk kebutuhan akses cepat menuju bandara Syamsudinnor dengan membuat jalan tembusan yang sangat luas dari km. 17 untuk akses dari daerah Banjarmasin dan juga jalan ke arah kota Martapura untuk akses kota Martapura dan sekitarnya. Akan tetapi, dimanfaatkan sangat baik oleh pihak bandara syamsyudinnor untuk membangun tempat olahraga yang sangat sejuk dikarenakan tempatnya yang strategis. 
Jalur yang menjadi satu rute inilah yang kini digemari oleh kalangan orang untuk bisa berolahraga dan menjadi tempat pilihan wisata olahraga yang sangat direkomendasikan di Banjarbaru tidak hanya di daerah kantot gubernur saja. Terlihat banyak sekali goweser yang menyasar rute ini dikarenakan jalan yang sangat nyaman dan luas. Jalur ini memiliki pemandangan dan suasana sangat asri dikarenakan masih dikelilingi oleh kebun-kebun hingga semak-semak yang sangat luas dan juga sungai kecil yang membuat orang yang berolahraga melewati jalur ini pada suasana pagi maupun sore sangat menyenangkan.

Setiap hari para komunitas sepeda maupun orang yang sekedar berolahraga di kawasan ini kian meningkat, akan tetapi menurut saya dengan meningkatnya jumlah pesepeda dan juga jumlah orang yang berolahraga seharusnya tidak menimbulkan kerumunan yang berbahaya bagi kesehatan. Selain itu kondisi jalur yang masih belum ramai penduduk juga meningkatkan pelaku kejahatan disekitaran jalur menuju bandara Syamsudinnor. Pihak pemerintah maupun pihak dari bandara sudah seharusnya bekerjasama untuk menangani kedua permasalahan tersebut.

\section{A. JALUR DAN RUTE}

Ada beberapa rute atau jalur yang dapat ditempuh untuk menuju ke lokasi wisata olahraga kawasan bandara syamsudinnor Banjarbaru. Ada dua rute utama yang paling sering digunakan untuk menuju ke lokasi yaitu :

\section{JALUR ARAH KM. 18}

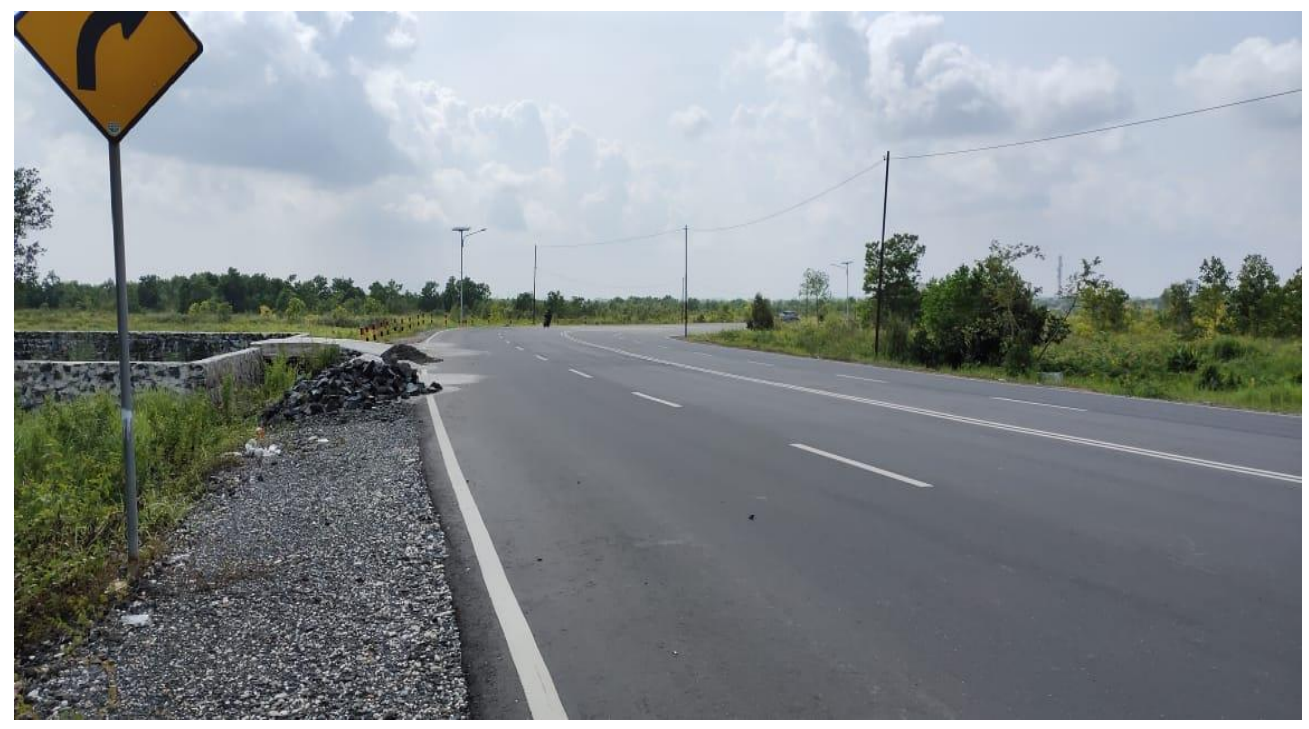




\section{Gambar Jalur km. 18 menuju lokasi wisata olahraga bandara syamsudinnor}

Jalur ini merupakan jalur yang sangat populer dan bisa dibilang menjadi jalur paling ramai dilewati ketika hendak menuju lokasi wisata olahraga kawasan bandara syamsudinnor Banjarbaru. Jalur ini sering dilewati orang-orang untuk berolahraga dari arah Banjarmasin, Gambut, Landasan Ulin, Liang anggang, dan juga dari Banjarbaru. Tidak heran banyak sekali para pesepeda maupun orang berolahraga jogging melewati kawasan ini dikarenakan pada saat pagi udara disini sangat sejuk dan tidak banyak kendaraan bermotor yang berlalu-lalang.

Selain itu disepanjang jalan ini masih sangat asri dengan pemandangan berupa semak dan sungai-sungai kecil menjadikan tempat ini memiliki udara yang sejuk pada pagi hari. Beberapa kebun jeruk juga dapat ditemukan disepanjang jalur ini sehingga tidak mudah bosan untuk melewati jalur ini sebelum menuju ke wisata olahraga bandara syamsudinnor.

\section{RUTE MARTAPURA DAN BANJARBARU KOTA}

Rute ini juga menjadi opsi khususnya goweser sepeda dari arah Martapura maupun dari arah Banjarbaru kota dikarenakan jalur ini sangat mendukung untuk daerah tersebut. Dengan rute yang lumayan jauh, jalur ini sangat cocok bagi para pesepeda dari arah kota Martapura dan Kota Banjarbaru walaupun tidak seramai jalur tembusan km.18.

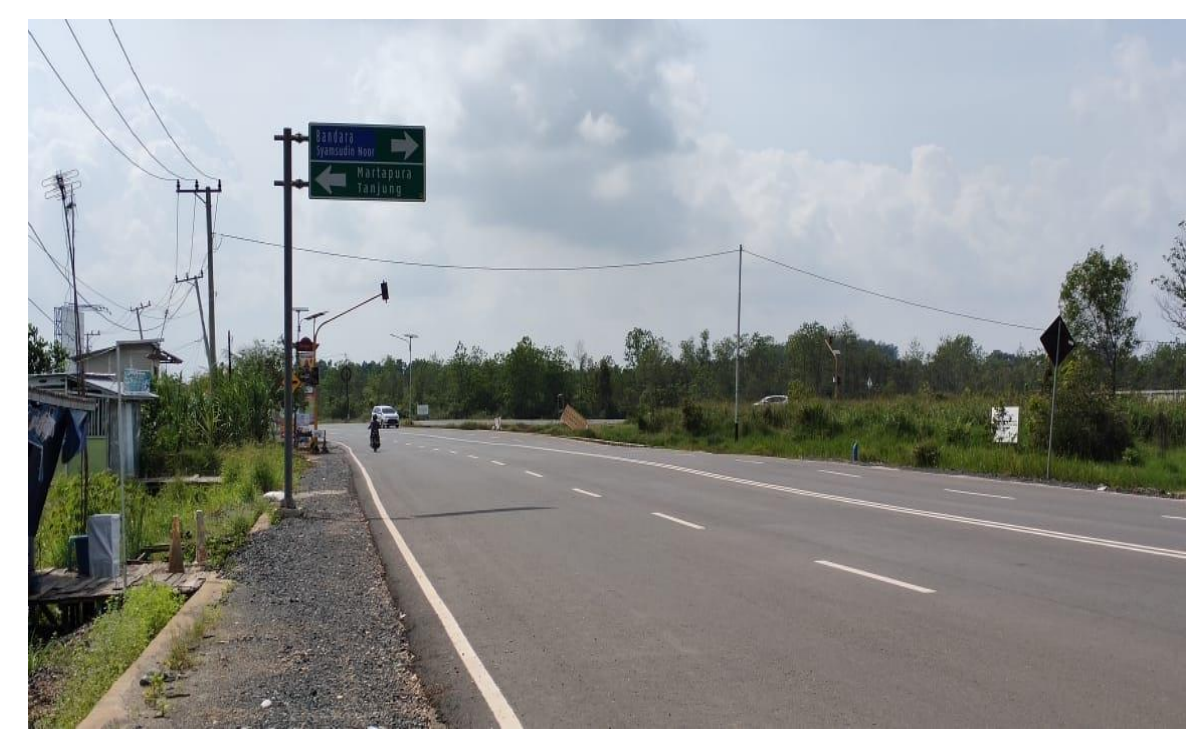

Gambar Persimpangan Jalur km.18 dengan jalur Martapura 
Jalur ini juga dikelilingi dengan pohon-pohon dan semak serta beberapa sungai kecil hampir sama seperti jalur km.18 akan tetapi, jalur ini masih terbilang cukup ramai kendaraan roda dua maupun empat yang berlalu lalang dikarenakan jalur ini merupakan jalur yang berhubungan langsung dengan martapura maupun Banjarbaru kota. Sehingga membuat para pesepeda lebih berhati-hati ketika melewati jalur ini.

\section{B. PROTOKOL KESEHATAN}

Protokol kesehatan kawasan wisata olahraga bandara Syamsudinnor Banjarbaru terbilang cukup ketat. Mengingat kawasan ini juga sangat erat hubungannya dengan wisatawan asing dan banyak orang akan tetapi, protokol kesehatan yang diterapkan oleh pihak bandara syamsudinnor untuk para olahragawan yang berkunjung terbilang sudah cukup bagus.

Setiap saat para petugas keamanan selalu mengingatkan orang-orang yang berolahraga untuk tetap menggunakan masker, boleh dilepas masker akan tetapi, hanya sebentar untuk mengatur pernafasan. Untuk mendukung fakta dilapangan, dibutuhkan subjek penelitian atau narasumber yang berpengalaman langsung dalam menangani masalah keamanan di bandara Syamsudinnor. Subyek penelitian adalah pihak yang berdasarkan berbagai pertimbangan dinilai memiliki kualitas dan ketepatan untuk berperan sebagai subyek penelitian sesuai dengan tujuan penelitian (Mutiani 2019).

"Kami menerapkan protokol kesehatan sesuai standart pemerintah dan pihak bandara syamsudinnor yaitu mewajibkan seluruh pesepeda, orang jogging, maupun orang-orang senam untuk memakai masker dan khusus untuk senam yaitu memberi jarak 1-2 meter setiap orang nya". Imbuh salah satu petugas keamanan di kawasan bandara syamsuddinnor.

"Akan tetapi kami mengizinkan apabila ada yang membuka masker hanya sekedar untuk mengatur pernafasan dengan syarat harus menjauh dari orang sekitar dan memasang masker nya segera". Dengan penerapan protokol ini, sudah cukup 
membantu bagi para pelaku olahraga yang berkunjung ke kawasan wisata olahraga bandara syamsudinnor Banjarbaru.

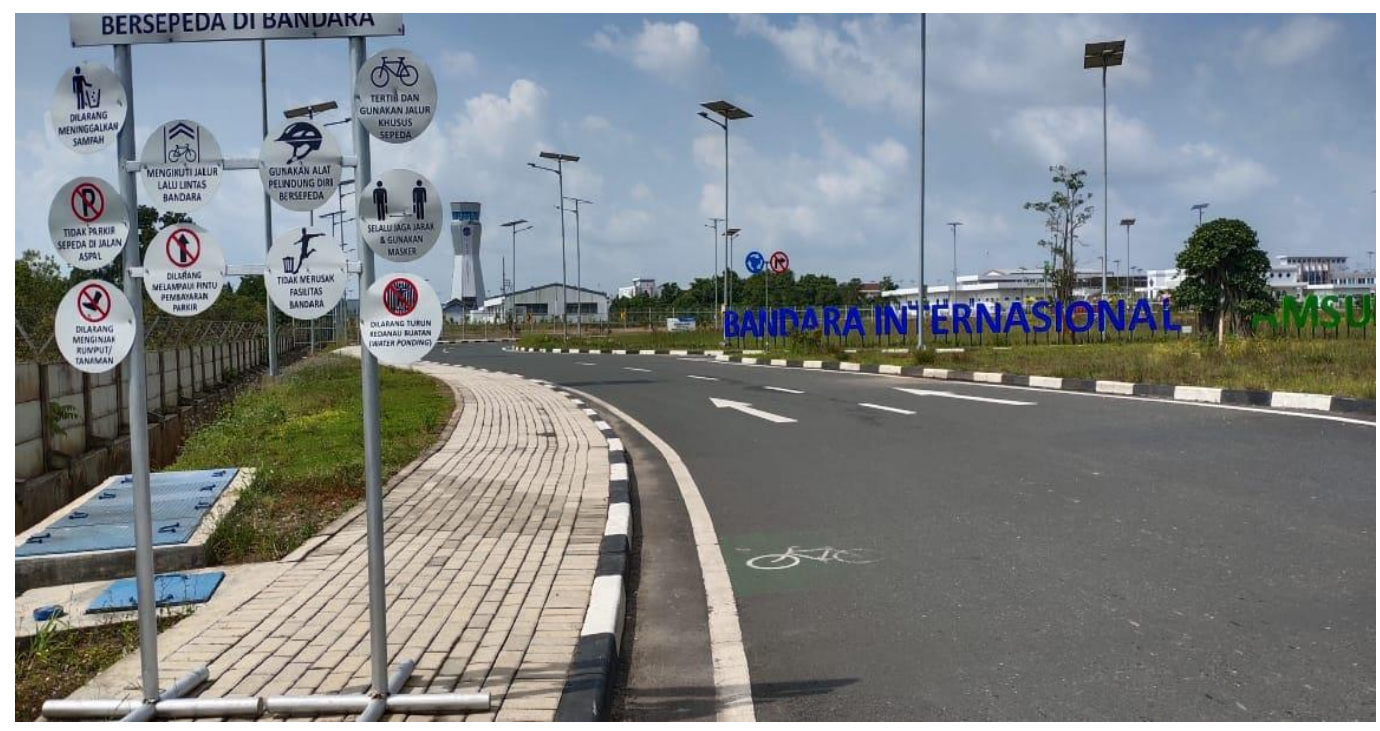

Gambar kawasan wisata olahraga bandara syamsudinnor Banjarbaru.

Dilihat dari gambar diatas merupakan tempat utama bagi para pesepeda maupun orang yang berolahraga joging untuk dikunjungi dan terlihat beberapa peraturan umum yang wajib dipatuhi para pengunjung ketika hendak berolahraga.

Demi terciptanya kawasan yang nyaman, sejuk, dan bersih, pihak bandara sangat menekankan kerjasama antarpihak untuk menajaga lingkungan kawasan wisata olahraga bandara syamsudinnor ini menjari tempat yang layak untuk dijadikan tempat olahraga bagi semua kalangan karena tempatnya yang sangat nyaman.

\section{SIMPULAN}

Dengan adanya fasilitas penunjang olahraga untuk kebutuhan masyarakat di kala pandemi saat ini sangatlah berarti dan sekaligus mendukung kesehatan masyarakat khususnya daerah Banjarbaru. tersedianya rute penunjang untuk menuju area bandara yang terbilang masih sangat baru juga menjadi daya tarik tersendiri dikarenakan rute yang ditempuh untuk menuju kelokasi terbilang sangatlah sejuk dan mendukung untuk berolahraga. Dengan tetap mematuhi protokol kesehatan yang ada pada saat berolahraga, para petugas keamanan di 
bandara Syamsudinnor dengan ketatnya mengawasi para masyarakat yang hendak berolahraga di dalam area sekitar bandara. 


\section{DAFTAR ISI}

Abbas, E. W. (2019). Building Nation Character Through Education: Proceeding International Seminar on Character Education.

Ashadi, K., Andriana, L. M., \& Pramono, B. A. (2020). Pola aktivitas olahraga sebelum dan selama masa pandemi covid-19 pada mahasiswa fakultas olahraga dan fakultas non-olahraga. Jurnal SPORTIF: Jurnal Penelitian Pembelajaran, 6(3), 713-728.

Biondi, B. (2021). Penerapan Protokol Kesehatan oleh Divisi Corporate Communication PT. Citilink Indonesia pada masa COVID-19 (Doctoral dissertation, Universitas Pelita Harapan).

Deasy, A. (2020). PENGARUH TINGKAT KEBISINGAN AKIBAT LALU LINTAS PESAWAT DI BANDARA SYAMSUDIN NOOR TERHADAP KOMUNIKASI MASYARAKAT DI KELURAHAN SYAMSUDIN NOOR KELURAHAN GUNTUNG PAYUNG DAN KELURAHAN LANDASAN ULIN TIMUR. JPG (Jurnal Pendidikan Geografi), 2(4), 16-28.

Masrun, M., Ruslan, M., Mahyudin, I., \& Rizali, A. (2016). Analisis Penerapan Konsep Eco-Airport Dengan Menggunakan Metode Willingness to Pay di Bandar Udara Syamsudin Noor Banjarmasin Kalimantan Selatan. EnviroScienteae, 12(3), 247-255.

Mutiani, M. (2019). INTERNALISASI NILAI PENDIDIKAN MELALUI AKTIVITAS MASYARAKAT SEBAGAI SUMBER BELAJAR ILMU PENGETAHUAN SOSIAL. INTERNALISASI NILAI PENDIDIKAN MELALUI AKTIVITAS MASYARAKAT SEBAGAI SUMBER BELAJAR ILMU PENGETAHUAN SOSIAL.

Nasih, M., Abbas, E. W., \& Syaharuddin, S. (2019). Nilai-Nilai Haul Guru Sekumpul Sebagai Sumber Belajar IPS. Jurnal Socius, 8(2).

Normajatun, N., \& Haliq, A. (2019). ANALISIS KEPUASAN MASYARAKAT TERHADAP PELAYANAN PUBLIK DI BANDAR UDARA INTERNASIONAL SYAMSUDIN NOOR BANJARMASIN. AS-SIYASAH: Jurnal Ilmu Sosial Dan Ilmu Politik, 4(1), 20-25.

Subiyakto, B., \& Mutiani, M. (2019). Internalisasi nilai pendidikan melalui aktivitas masyarakat sebagai sumber belajar ilmu pengetahuan sosial. Khazanah: Jurnal Studi Islam dan Humaniora, 17(1), 137-166. 
Syaharuddin, S. (2020). Menimbang Peran Teknologi dan Guru dalam Pembelajaran di Era COVID-19. Menimbang Peran Teknologi dan Guru dalam Pembelajaran di Era COVID-19. 